\title{
Regulation of universities as charities: one step forward, two steps back
}

\author{
Mary Synge $e^{\star \dagger}$ (D) \\ University of Exeter, Exeter, UK \\ *Author email: m.k.synge@exeter.ac.uk
}

(Accepted 10 November 2020)

\begin{abstract}
Most universities (bar profit-making institutions) are charities as a matter of law but, historically, have been exempt from charity law regulation. This paper considers the statutory reforms of 2006, which sought to level the regulatory playing field by appointing 'Principal Regulators' of such 'exempt charities' to promote compliance with charity law. Focusing on the university sector - where some universities are now registered charities (and regulated by the Charity Commission) whilst others remain exempt - it will note how the reforms have resulted in the application of significantly different degrees of scrutiny and accountability, both between individual universities and between universities and other charities. In part, this is due to the statutory framework itself but, significantly, is also attributable to the radically different approach taken by the Office for Students, which replaced HEFCE as Principal Regulator in 2018. Possible improvements in regulatory practice and statutory reform are offered.
\end{abstract}

Keywords: charity law; property and trusts; universities; Office for Students; exempt charities; regulation

\section{Introduction}

There are at least three little-known facts about universities. First, generally speaking and as a matter of law, they are charities and most are described as 'exempt charities'. Second, as exempt charities -so called because, historically, they were exempt from the regulatory jurisdiction of the Charity Commissioners and, later, from the need to register publicly - universities are, and have always been, as much charities and subject to the fundamental principles of charity law as any other charity. Third, significant changes were made to the legislative framework for charities in 2006 that were designed, in part, to level the playing field between universities and other charities and to promote compliance with charity law by the former through increased regulation.

It is suggested that the policy behind those reforms was both timely and sound, not least because charity law, which seems to be commonly misunderstood or overlooked, has much to contribute to contemporary discourse about the university sector. The form that the reforms took, however, and their subsequent implementation - particularly by the Office for Students (OfS) - have failed to deliver the desired outcomes. If effective regulation is to be achieved, and it is vital that it is, steps are needed to improve and strengthen the reforms that were made and their observance in practice.

\footnotetext{
${ }^{\dagger}$ Associate Professor, University of Exeter; Honorary Senior Research Fellow, University of Liverpool. My sincere thanks to Tim Dodsworth, Andrea Lista, Rebecca Probert, Deborah Cochrane and Christine Bicknell for their comments on an earlier draft. The insightful and constructive observations of the anonymous reviewers, for which I am most grateful, have also resulted in a much-improved paper. Any errors remain my own.

(c) The Author(s), 2021. This is an Open Access article, distributed under the terms of the Creative Commons Attribution licence (http://creativecommons.org/licenses/by/4.0/), which permits unrestricted re-use, distribution, and reproduction in any medium, provided the original work is properly cited.
} 


\section{(a) Background}

The Charities Act 2006 (2006 Act) - subsequently consolidated in the Charities Act 2011 (2011 Act) sought to improve public trust and confidence in charities in various ways. One of these was by extending regulatory oversight to exempt charities, either by requiring them to register with and be regulated by the remodelled Charity Commission (Commission), ${ }^{1}$ or by appointing an alternative regulator to promote their compliance with charity law. The universities of England and Wales, including the colleges and halls of Oxford, Cambridge and Durham, ${ }^{2}$ comprised one such category of exempt charity. For reasons unrelated to charitable status, the implementation of these reforms has meant that some universities are now registered with the Commission, whilst others remain exempt and are overseen by a 'Principal Regulator'. Initially this role was undertaken by the Higher Education Funding Council for England (HEFCE) but, following HEFCE's abolition in 2018, is now performed by the OfS. The result is a two-tier regulatory regime that subjects universities to quite different levels of oversight. In part this is attributable to the legislative framework itself, but the inconsistency is exacerbated by the OfS's approach, which marks a radical departure from its predecessor's close alignment with the Commission.

\section{(b) Scope of the paper}

There appears to be a general lack of appreciation of what constitutes 'charity law', and of the significance of a university's charitable status, which merits fundamental and extensive scrutiny. Academic commentary, official publications and media reports reveal multiple concerns regarding the university sector, including top-down management and poor accountability, excessive executive pay and unmanaged conflicts of interest, falling educational standards and grade inflation. ${ }^{3}$ In all such accounts, however, the charitable status of universities, and the significance of that status, is strikingly absent. ${ }^{4}$ The first task, therefore, is to provide an outline of 'charity law', which can be seen to speak directly to many of these issues. The second is to indicate why regulatory oversight of compliance with that law by charities, not least universities, is critical.

The current landscape for charity law regulation of universities will then be analysed, first by addressing the fundamental divide between registered and exempt charities and, second, by interrogating a number of issues that highlight the further divide particular to universities, taking account of the replacement of HEFCE by the OfS. It will be suggested that the two-tier regime is incoherent and indefensible, that the OfS is neither effective nor suitable as Principal Regulator, and that all universities should be registered and overseen (as charities) by the Commission. The 2006 Act invited renewed focus on the charitable status of our universities and, in response to its specific provisions, possible reform of the legislative framework and improvements to regulatory practice are outlined here. ${ }^{5}$

\section{Charity, charity law and the need for charity law regulation}

No two universities are the same and the diversity in terms of their history, size, legal status and resources, is considerable. Charitable status, on the other hand, is a feature common to almost all.

\footnotetext{
${ }^{1} 2006$ Act, s 6, replacing the Charity Commissioners (established by the Charitable Trusts Act 1853).

${ }^{2}$ The term 'university' will be used to denote all (as in eg Equality Act 2010, s 94(4)). This paper is concerned with England and Wales only: universities in Scotland and Northern Ireland are subject to separate regulation.

${ }^{3}$ Examples are too numerous to list, but see eg S Collini Speaking of Universities (London: Verso, 2017); J Frank et al English Universities in Crisis (Bristol: Bristol University Press, 2019); House of Commons Education Committee Value for Money in Higher Education, Seventh Report of Session 2017-19, HC 343, 5 November 2018 (HC, 2018); T Richmond 'A degree of uncertainty: an investigation into grade inflation in universities' (Reform Research Trust, June 2018).

${ }^{4}$ Exceptionally, textbooks describe universities' charitable status but do not examine its significance in detail, eg D Farrington and D Palfreyman The Law of Higher Education (London: Oxford University Press, 2nd edn, 2012 ) ch 7.

${ }^{5}$ The broader significance of charitable status, in terms of a university's operations and its relations with the state, will be explored elsewhere.
} 
Their place in the charity sector stems from their inclusion in a preamble to an Elizabethan statute, ${ }^{6}$ that became the touchstone for defining 'charity' in law, ${ }^{7}$ and challenges the common perception that universities are part of the public sector, or possibly the business sector. The more modern (and rather cryptic) statutory caveat, that universities are exempt charities 'in so far as they are charities', 8 may invite further interrogation on another occasion, but it will be assumed for the purposes of this paper that universities are, indeed, charities. ${ }^{9}$

As charities, universities enjoy considerable benefits, not least favourable tax treatment, including a minimum of $80 \%$ relief from business rates. ${ }^{10}$ At the same time, charitable status gives rise to extensive legal responsibilities and public expectations of exacting ethical standards.

\section{(a) Charity law}

...the 'law of charity is very particular and complex and requires more judgment [sic] on the part of those who apply it than most other parts of our law. ${ }^{11}$

Space allows only the briefest of summaries, but some understanding of the reach and relevance of 'charity law' is essential, as there is a danger that this is too narrowly construed and gravely misunderstood. Two points should be noted. First, the most fundamental charity law obligations are to be found in case law, rather than legislation. Secondly, compliance with them is not as easily monitored or regulated (as statutory obligations) and requires high levels of knowledge, integrity and internal checks and balances. ${ }^{12}$

Undoubtedly 'charity law' is not as easily recognised or located as, say, the law of contract, and its scope lies far beyond the provisions of the Charities Acts, some of which are considered below. Deriving principally from the law of equity and trusts, the law of charity imposes a complex range of duties on those persons responsible for administering a charity, typically referred to as trustees (regardless of the charity's (incorporated or unincorporated) legal form). ${ }^{13}$ These duties include a duty to act in accordance with the charity's constitution, exercising powers only for proper purposes and with appropriate care and skill. ${ }^{14}$ Essentially, this means that the members of a charity's governing body must further the purposes set out in the institution's constitution (which are necessarily charitable in law) and act in 'the best interests of the charity. ${ }^{15}$

This duty to act in the best interests of the charity is paramount, but may be little understood. In the context of advancing education, a 'functional purpose' - as opposed to an investment purpose of generating income and/or capital growth ${ }^{16}$ - is appropriate; this means in the best interests of fulfilling

\footnotetext{
${ }^{6}$ Statute of Charitable Uses 43 Eliz 1 c 4 (1601).

${ }^{7}$ eg Gilmour $v$ Coats [1949] AC 426 at 442.

${ }^{8} 2011$ Act, s 22(1).

${ }^{9}$ Excluding profit-making institutions, which are not charities.

${ }^{10}$ Local Government Finance Act 1988, ss 43, 47. For the tax benefits accompanying charitable status, see eg H Picarda The Law and Practice Relating to Charities (Haywards Heath: Bloomsbury Professional, $4^{\text {th }}$ edn, 2010) and First Supplement (Haywards Heath: Bloomsbury Professional, 2014) chs 55-57.

${ }^{11}$ Hansard HL Deb, vol 719, col 1629, 28 June 2010 (Lord Phillips).

${ }^{12}$ It has been observed that ' $[\mathrm{m}]$ any of the recent governance problems... can be traced to a breakdown in the system of checks and balances, when these are not clearly understood or respected by management or the Board of Governors' (Farrington and Palfreyman, above n 4, at para 5.06).

${ }^{13} 2011$ Act, s 177 defines 'charity trustees' as those persons 'having the general control and management of the administration of a charity' (at least for the purposes of the Act); see too D Palfreyman 'The law's view of university governors - power and authority, responsibility and unlimited personal financial liability' (Oxford Centre for Higher Education Policy Studies, March 2017) available at http://oxcheps.new.ox.ac.uk/oxcheps/policy.php?id=513. For duties of charity trustees generally see Picarda, above n 10, Part IV, esp ch 38.

${ }^{14}$ Harries $v$ Church Commissioners for England [1992] 1 WLR 1241 at 1246; Trustee Act 2000, s 1.

${ }^{15}$ Harries, ibid at 1246 . Some duties may extend beyond the governing body in some circumstances, eg to members of a charitable company: Lehtimaki v Cooper [2020] UKSC 33, [2020] 3 WLR 461.

${ }^{16}$ Harries, above n 14, at 1246.
} 
those purposes for the benefit of society generally. The strategic goals, set by a university's governing body, of maximising growth in income or student numbers, for example, might well be in the best interests of the institution's finances, but that is not the same thing at all. ${ }^{17}$ Likewise, a decision to pay an outgoing Vice-Chancellor for not offering his or her services to another university for a period of time might be understood to protect a university's competitive advantage, but may be difficult to reconcile with this overriding duty. And under charity law, the advancement of education is a charitable purpose for the public benefit because of the benefit to society as a whole; the benefits to individual scholars are incidental only: ${ }^{18}$ the political mantra to act in the best interests of the students, therefore, presents a fundamental conflict, at least in so far as the students' interests - as yet undefined - are understood to be different. ${ }^{19}$

Fiduciary duties also mean that fiduciaries, including trustees, must neither allow their own interests to conflict with the interests of the charity nor make any profit from their position, at least not without full disclosure and proper authorisation..$^{20}$ Recent revelations that $95 \%$ of university leaders were either members of, or attending, the committees that determined their remuneration raise important questions over their observance of the no-conflict rule. ${ }^{21} \mathrm{~A}$ fundamental principle of charity law demands that trustees act without remuneration, with very limited exceptions, ${ }^{22}$ and private benefit accruing to individuals associated with the charity's organisation is permitted only to the extent that it is reasonable and incidental. ${ }^{23}$ The juxtaposition of unpaid lay members and paid executive members of a governing body is commonplace in universities, but rare in the charity sector and means that governance issues require particular care. ${ }^{24}$ Compensation for loss of office, and other ex gratia payments, generally require consent from the Commission. ${ }^{25}$ Trustees may employ staff to run the charity, but should ensure that roles and responsibilities are clearly delineated and that terms of employment contracts are in the best interests of the charity. ${ }^{26}$ The need to justify high executive pay in terms of this paramount duty is evident in guidance for the charity sector, but its absence from university sector guidance may suggest that it is either unknown or considered irrelevant. ${ }^{27}$

The legal consequences of a breach of charity law are not always straightforward and cannot easily be summarised. ${ }^{28}$ In simple terms, however, it should be noted that members of governing bodies may incur personal liability for breach. ${ }^{29}$ It has been suggested that this liability may be most likely to attach to governors' inaction, including failing adequately to 'monitor and control [the] executive in whom they will have delegated significant management power', ${ }^{30}$ and that indemnity insurance should not be assumed 'automatically to compensate for ignorance and neglect'. ${ }^{31}$

\footnotetext{
${ }^{17}$ Of course, trustees must exercise sound financial management.

${ }^{18}$ London Hospital Medical College v IRC [1976] 1 WLR 613 at 620.

${ }^{19} \mathrm{~A}$ mandate for the OfS: see eg guidance from the Minister of State for Universities to the OfS, 20 February 2018, available at https://www.officeforstudents.org.uk/media/1111/strategicguidancetotheofs.pdf.

${ }^{20}$ eg Boardman v Phipps [1967] 2 AC 46; Conflicts of interest: a guide for charity trustees CC29 (Commission, May 2014); J Jackson and J Cowley 'Blinking dons or donning blinkers: fiduciary and charity obligations of members of governing boards of Australian universities' (2002) 6 Southern Cross University Law Review 8; Lehtimaki, above n 15 (members also fiduciaries).

${ }^{21}$ Transparency at the Top? The Fourth Report of senior pay and perks in UK universities (University and College Union (UCU), February 2018); the Fifth Report in respect of 2017-18 reveals a drop to 81\% (UCU, May 2019).

${ }^{22}$ Trustee Act 2000, ss 28-31; 2011 Act, s 185; or authorised (exceptionally) by the constitution, the Commission or the courts.

${ }^{23}$ eg IRC $v$ City of Glasgow Police Athletic Association [1953] AC 380.

${ }^{24}$ Typically including the Vice-Chancellor as a minimum; Conflicts of interest, above n 20.

${ }^{25} 2011$ Act, s 201 (charitable companies); s 106; Ex gratia payments by charities CC7 (Commission, May 2014).

${ }^{26}$ Subject also to the institution's own laws; and see Trustee Act 2000, s 11(3).

${ }^{27}$ See below (text to nn 147-151).

${ }^{28}$ See eg Farrington and Palfreyman, above n 4, at paras 7.28-7.37.

${ }^{29}$ Some breaches attract criminal liability, eg 2011 Act, ss 41 and 60.

${ }^{30}$ Jackson and Cowley, above n 20, at 63.

${ }^{31}$ Farrington and Palfreyman, above n 4, at para 7.31 .
} 


\section{(b) The need for regulation}

Public trust and confidence that institutions are honestly and effectively managed is especially important in a sector that is inspired and moulded by principles of trust, voluntarism and altruism, and the desire to improve this trust and confidence was a core priority of the 2006 Act. Effective regulation by the state is key, for several reasons. A regulatory framework that aims to discover and correct abuse and mismanagement in charities provides protection for the taxpayer, who funds generous tax privileges, government grants and contracts, and also encourages the voluntary donations and legacies on which many rely. Universities are not so different: in addition to tax reliefs and concessions, the taxpayer effectively funds teaching and research grants, ${ }^{32}$ and underwrites student loans. ${ }^{33}$ Many universities, particularly older institutions, benefit from historic endowments and modern fundraising campaigns continue to attract public donations and legacies. ${ }^{34}$

Perhaps a more important reason is that the means of oversight and enforcement which exist in noncharitable settings are typically absent, or less effective, in charities. A charitable trust, for example, lacks private beneficiaries who have undoubted rights of enforcement and a charitable company lacks the oversight of a body of shareholders. ${ }^{35}$ The courts' deference to trustees' discretion and a protective filter on charity proceedings also mean that challenges to a charity's governance and operations are rare. ${ }^{36}$ And reliance on the traditional role of the Attorney General, as the protector and enforcer of charity, is increasingly inadequate in a sector which is as diverse, vast and significant as the modern charity sector. ${ }^{37}$

In the university sector, the existence of a 'Visitor', with jurisdiction over the private laws of the institution, was undoubtedly one of the reasons for exemption from the jurisdiction of the Charity Commissioners. ${ }^{38}$ The office is limited to chartered corporations, however, and statutory curtailment of that special jurisdiction has contributed significantly to a general demise in the Visitor's role, largely removing an important check on a university's compliance with its legal obligations. ${ }^{39}$ The exponential increase in the size of universities, together with decreasing levels of transparency (in many respects) and the increasing gulf between academics and those who run them, make challenges by academics and other stakeholders considerably less likely.

Weak enforcement mechanisms render charities especially susceptible to abuse, and current reports of the 'lowest level' of public trust and confidence in the charity sector, though they can hardly be attributed to universities, ${ }^{40}$ suggest an urgent need for greater awareness of charity law as well as greater levels of trust and integrity. ${ }^{41}$ The need for effective regulation may be even greater in respect of universities, where the lack of historical oversight, for charity law purposes, has undoubtedly encouraged ignorance of the fact that they are charities, or perhaps more accurately, an ignorance of the charity law to which they are subject. ${ }^{42}$

\footnotetext{
${ }^{32}$ At least those funded by government or government-funded research bodies.

${ }^{33}$ The decision to reclassify amounts written off as public spending has highlighted the cost to the taxpayer: Office for National Statistics New treatment of student loans in the public sector finances and national accounts (ONS, December 2018).

${ }^{34}$ Also benefiting from favourable tax treatment: Picarda, above $\mathrm{n} 10$, ch 55 . Oxford University, for example raised $£ 3.3 \mathrm{bn}$ between 2004 and 2019: https://www.development.ox.ac.uk/news/three-billion-raised-through-the-oxford-thinking-campaign.

${ }^{35}$ Note eg extended powers to shareholders in respect of executive pay in quoted companies (Companies Act 2006, ss 226A-226F). A charity-company is usually a company limited by guarantee. Universities' governance structures vary considerably, but reduced participation by academic staff is a recurring theme in the literature: eg M Shattock and A Horvath The Governance of British Higher Education (London: Bloomsbury Academic, 2020).

${ }^{36} 2011$ Act, s 115 .

${ }^{37}$ One reason for establishing the new Commission in the 2006 Act. There are currently more than 168,000 registered charities alone: Charity Commission Annual Report and Accounts 2019-2020 (HC 507, 20 July 2020) p 10.

${ }^{38}$ Typically, a representative of the founder or monarch; Farrington and Palfreyman, above $\mathrm{n}$ 4, at paras 12.68-12.71.

${ }^{39}$ Higher Education Act 2004, ss 20, 46; J Bridge 'Keeping peace in the universities: the role of the Visitor' (1970) 86 LQR 531.

${ }^{40}$ Not (typically) being associated with the charity sector.

${ }^{41} \mathrm{eg}$ Statement of Strategic Intent 2018-2023 (Commission, 4 October 2018).

${ }^{42}$ University-based investigations tend to focus on executive pay and unmanaged conflicts, but - for obvious reasons charity law has not been their main focus (even where conducted by the Principal Regulator): eg Report of an enquiry
} 
It will be seen, below, that the full reach of charity law might not have been appreciated and that the regulatory processes, though valuable, are not as effective as they might be.

\section{Exempt charities and the revision of the regulatory framework}

... the law on exempt charities is an incredibly complex area with a complex history. ${ }^{43}$

When the public register of charities was introduced by the Charities Act 1960, charities were (and are still) categorised in three ways: ${ }^{44}$ 'registered charities', which are entered on the register and subject to the full supervisory and regulatory jurisdiction of the Commission; 'excepted charities', which are subject to that jurisdiction but not required to be registered; ${ }^{45}$ and 'exempt charities', which are excluded from both the need to register and the regulatory oversight of the Commission.

Among the first exempt charities were the Church Commissioners, the British Museum and universities. ${ }^{46}$ The rationale for their exemption was that they were adequately supervised by another body, and perhaps because they were also deemed to be beyond reproach. ${ }^{47}$ The concept of an 'exempt charity' was not new: broadly speaking these charities had also been exempted from the jurisdiction of the Charity Commissioners in 1853 , for the same reason. ${ }^{48}$ Unfortunately, the word 'exempt' is apt to mislead and needs to be properly understood: ${ }^{49}$ exempt charities are - and have always been - as much charities as registered and excepted charities and equally subject to fundamental principles of charity law.

\section{(a) The 2006 reforms}

The 2006 Act sought to modernise the legal and regulatory framework for the charity sector: the existence of 'exempt' and 'excepted' charities was seen as anomalous and confusing, and a threat to the integrity of charitable status. ${ }^{50}$ There was a realisation that such oversight as did exist over exempt charities did not extend to regulation of them as charities and it was reported that some appeared 'unaware' of the 'governance arrangements and stewardship of funds' required of them. ${ }^{51}$ Improving public trust and confidence required high levels of transparency and accountability, together with robust regulation. Achieving a 'level playing field' across the sector was also key and was as much a goal in terms of regulation and compliance as it was about establishing, or requiring institutions to justify, their charitable status by providing evidence of their 'public benefit'. ${ }^{52}$

into a governance matter at the University of Bath (HEFCE, November 2017); Statement and Action Plan re De Montfort University (OfS, July 2019): available at https://www.officeforstudents.org.uk/news-blog-and-events/press-and-media/demontfort-university/.

${ }^{43}$ Hansard HL Deb, vol 729, col 93, 5 July 2011 (Baroness Verma).

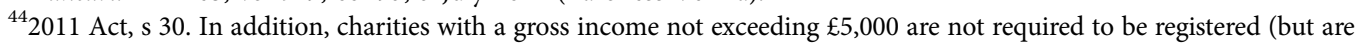
neither 'exempt' nor 'excepted').

${ }^{45}$ Principally certain religious institutions, scouts, guides and armed forces charities.

${ }^{46}$ Charities Act 1960, Sch 2; now listed in 2011 Act, Sch 3, they include various museums, galleries, further education corporations, schools and social housing providers.

${ }^{47}$ Sometimes resting on an assumption that universities are 'full of lawyers, accountants and managers': Hansard HL Deb, vol 670, col 300GC, 8 March 2005 (Lord Phillips); Exempt Charities CC23 (Commission, September 2013) at 2.2.

${ }^{48}$ Charitable Trusts Act 1853, s LXII; see J Fishman 'Charitable accountability and reform in nineteenth ventury England: the case of the Charity Commission' (2005) 80 Chicago-Kent Law Review 723, for an interesting account of the universities' power in resisting charity law reform.

${ }^{49}$ Inaccurately described, for example, in the Explanatory Note to The Exempt Charities Order 2004, SI 2004/1995.

${ }^{50}$ Cabinet Office Strategy Unit Private Action, Public Benefit: A Review of Charities and the Wider Not-For-Profit Sector (Cabinet Office, September 2002) para 7.94.

${ }^{51}$ Ibid; see too Minister for the Cabinet Office Trusted and Independent: Giving charity back to charities (TSO, July 2012) para 6.3 (partly attributing the 2006 reforms to 'some high profile cases of mismanagement' and noting 'little visibility over this large group of about 10,000 charities, many of whom have very significant resources' (para 6.2)); Exempt Charities, above n 47 , para 2.2 .

${ }^{52}$ Private Action, above n 50, para 7.89 (fee-charging independent schools being the most targeted). 
The 2006 Act, therefore, extended accountability and regulation in the sector by requiring increasing numbers of excepted charities to be entered on the register, and by requiring exempt charities either to be registered or, whilst remaining 'exempt', to be subject to regulatory oversight by other means. Arguments that the Commission would be best suited to regulate these additional categories of charity were rejected and, instead, the Act provided for the designation of 'Principal Regulators' ${ }^{53}$ The rationale was that these bodies or ministers would be able to monitor and regulate compliance by exempt charities just as well as the Commission and, ${ }^{54}$ given their existing sector-specific roles, would minimise the bureaucratic burden, thus allowing the time and cost inefficiencies of dual regulation to be avoided. ${ }^{55}$

Protestations that the university sector was 'already heavily over-regulated', 56 and 'fully aware of charity law ${ }^{57}$ were overruled. From now on, universities would still be described as 'exempt charities', but they should be enabled, and required, to demonstrate their compliance with charity law. ${ }^{58}$ Policy interests of transparency and equal treatment were also about reassuring the public, and no doubt satisfying government, that these organisations deserved the multiple privileges that their charitable status gave them (whether or not registered), most notably tax concessions. ${ }^{59}$

\section{(b) HEFCE, the first Principal Regulator of exempt universities}

Notwithstanding concerns arising from the historic neglect of exempt charities in terms of charity law regulation, universities were generally perceived to be 'low-risk' and there was little or no suggestion in Parliament that they were failing to comply with 'basic charity law requirements' ${ }^{60}$ The objective of ensuring 'proper regulation', 61 therefore, was to be satisfied by a risk-based framework, which balanced the need to be 'properly accountable' with a desire to minimise the bureaucratic burden. ${ }^{62}$ Accordingly, the first designated Principal Regulator for universities (from 2010) was HEFCE, ${ }^{63}$ the body primarily responsible for distributing public funds for research and teaching among universities and colleges. ${ }^{64}$ Concerns over a potential conflict between its roles as both funder and regulator were dismissed, and its professed willingness to adopt a light regulatory touch was welcomed by many. ${ }^{65}$

Although it had no specific resources for its role and 'limited technical expertise in charity law', 66 HEFCE's ambition was clearly to mirror the Commission's role so far as it could and it took a relatively proactive approach, demanding and scrutinising the sort of information that the Commission required of registered charities and carrying out five-yearly reviews that involved site visits and offering advice. $^{67}$ For HEFCE, this responsibility brought benefits, both to its own strategic interests, in improving governance processes at higher education institutions, and to the public, by improving public understanding and confidence. More particularly, it observed that greater recognition of universities as charities would lead to further benefits, inter alia, by improving community engagement,

\footnotetext{
${ }^{53} 2006$ Act, s 13; Joint Committee on the Draft Charities Bill, The Draft Charities Bill HL 167-I, HC 660-I, 30 September 2004, para 363 (noting evidence submitted by the BTCV).

${ }^{54}$ Hansard HL Deb, vol 670, col 408GC, 14 March 2005.

${ }^{55}$ For all concerned: Joint Committee, above n 53, para 366.

${ }^{56}$ Hansard, above n 47, col GC299 (Lord Hunt).

${ }^{57}$ Ibid, col 300GC (Lord Phillips).

${ }^{58}$ Ibid, col 304GC.

${ }^{59}$ Above n 10; Joint Committee, above n 53, paras 355, 356.

${ }^{60}$ Above n 58 (Lord Bassam); Written Evidence to the Joint Committee, above n 53, from Universities UK (DCH 315).

${ }^{61}$ Hansard, above n 54, col 408GC (Lord Hodgson).

${ }^{62}$ Hansard, above n 47, col 303GC (Lord Bassam).

${ }^{63}$ The Charities Act 2006 (Principal Regulators of Exempt Charities) Regulations 2010, SI 2010/501.

${ }^{64}$ Further and Higher Education Act 1992, s 62.

${ }^{65}$ Hansard, above n 47, cols 298-299GC. HEFCE concluded that it could accommodate both roles 'with little risk of a significant conflict': HEFCE's approach to working as principal regulator (HEFCE, undated).

${ }^{66}$ HEFCE's approach, ibid, para 4.

${ }^{67}$ HEFCE's approach, ibid.
} 
governance and management, reputation, charitable activity and donations. ${ }^{68}$ These were laudable aims that continue to deserve attention.

\section{(c) The higher education sector}

Denied the option of avoiding regulation altogether, universities in England and Wales went in one of two directions. No doubt aware of criticisms levelled at the Commission's regulatory approach, most English universities thought their chances of success in 'fight[ing] the battle for a light-touch regulatory approach' were greater with HEFCE than with the Commission and welcomed their continuing 'exempt' status. ${ }^{69}$ In the absence of a suitable Principal Regulator, however, the Welsh universities, and the colleges and halls of Oxford, Cambridge and Durham, registered with the Commission. ${ }^{70}$

\section{The two tiers of the new regulatory framework}

Evidently, the intention behind the 2006 Act was to ensure that exempt charities complied, and were seen to comply, with charity law to the same extent as all registered charities, albeit with the minimum bureaucracy possible. That this has not been achieved is due, in part, to the statutory provisions themselves: first, because they assigned different roles and powers to the Commission and Principal Regulator (noted in (a) below) and, secondly, because, in imposing some mandatory requirements, they differentiated between registered and exempt charities (highlighted in (b) below).

\section{(a) The fundamental divide between registered and exempt charities}

The term 'Principal Regulator' does appear to be something of a misnomer. The statutory role and powers make it more of an information-gatherer than a controller or enforcer.

\section{(i) Statutory roles}

One of the Commission's five statutory objectives is 'to promote compliance by charity trustees with their legal obligations in exercising control and management of the administration of their charities. ${ }^{71}$ It is also set up to identify, investigate and take action in respect of misconduct and mismanagement. ${ }^{72}$ The Principal Regulator's role, on the other hand, is to 'do all that [it] reasonably can' to promote such compliance. ${ }^{73}$ The different wording acknowledges the Principal Regulator's lesser powers (noted below), but the bar it sets is nonetheless high.

\section{(ii) Powers of the Commission: statutory inquiries}

The Commission's principal regulatory tool is the statutory inquiry, which allows it to investigate a charity's affairs for general or particular purposes. ${ }^{74}$ In the event that misconduct or mismanagement is discovered, ${ }^{75}$ the Commission may take several courses of action, including suspending or removing a trustee or employee, or appointing an interim manager. ${ }^{76}$ Alternatively, it may direct certain actions

\footnotetext{
${ }^{68}$ Impact Assessment for: Regulation of HEIs as Charities (HEFCE, 9 August 2016).

${ }^{69}$ Hansard, above n 47, col 299GC (Lord Hunt). Criticisms of a heavy-handed approach by the Commission were not uncommon: see eg Hansard, above n 54, cols 436GC-452GC.

${ }^{70}$ Exempt Charities, above n 47; described as an arrangement with which the colleges were happy: Hansard, above n 47, cols 294-295GC; the University of Buckingham is also registered.

${ }^{71} 2011$ Act, s 14.

${ }^{72}$ Ibid, s 15.

${ }^{73}$ Ibid, s 26(2), (3).

${ }^{74}$ Ibid, s 46.

${ }^{75}$ Or failure to comply with orders etc (ibid, s 76).

${ }^{76}$ Ibid, ss 76, 79 .
} 
to be taken, or not taken, or the winding up of the charity. ${ }^{77}$ Excessive remuneration, a charge sometimes levelled at universities, is stated as one example of such misconduct or mismanagement. ${ }^{78}$

The Principal Regulator has no such powers, but may request the Commission to conduct an inquiry into an exempt charity and the Commission cannot do so without such a request. ${ }^{79}$ It is important, therefore, that there is appropriate and adequate information available to the Principal Regulator, and others, ${ }^{80}$ to recognise when an inquiry might be necessary or desirable. It is also important that a Principal Regulator makes such a request where appropriate and that the prospect of a request signalling a failure of the Principal Regulator's responsibilities up to that point does not make it unduly reluctant to do so. ${ }^{81}$ In the absence of such a request, exempt charities may enjoy some measure of immunity.

By way of illustration, when HEFCE investigated allegations of conflicts of interest and excessive executive pay at the University of Bath in 2017, its actions were prompted by a public interest disclosure, rather than its own monitoring processes, and the Commission was not requested to conduct an inquiry. ${ }^{82}$ Whether the Commission would have opened an inquiry in response to a similar whistleblowing report in respect of Cardiff University or Balliol College, for example, is open to question. ${ }^{83}$

\section{(iii) Other powers of the Commission}

Regardless of whether a statutory inquiry is instituted, the Commission has further powers which are not dependent upon a request from the Principal Regulator or charity although, if related to an exempt charity, it must consult with the Principal Regulator before acting. ${ }^{84}$ Thus it may also call for documents and search records for any reason connected with the discharge of its broad functions. ${ }^{85}$ Similarly it may direct application of charity property, ${ }^{86}$ disqualify a person from acting as a trustee or in senior management, ${ }^{87}$ or issue a formal warning to a charity or charity trustee where it considers that a breach of trust or duty or other misconduct or mismanagement has been committed. ${ }^{88}$ The Commission may also remove a trustee on several grounds, including failure to act, ${ }^{89}$ but this power is disapplied in the case of an exempt charity unless an inquiry has been instituted. ${ }^{90}$

The Principal Regulator has no such powers under the regulatory framework. Under the Higher Education Research Act 2017, the OfS has powers to request information, ${ }^{91}$ to deregister or suspend registration, ${ }^{92}$ and to impose monetary penalties. ${ }^{93}$ These reflect its role as regulator and registrar of all higher education institutions, however, rather than as overseer of charitable ones. In the report following its investigation at the University of Bath, ${ }^{94}$ HEFCE noted its position as Principal Regulator, ${ }^{95}$ but

\footnotetext{
${ }^{77}$ Ibid, ss $84,84 \mathrm{~B}$.

${ }^{78} \mathrm{Ibid}$, s 76(2); see too s 76A. Undue focus on avoiding critical media coverage, or failure to implement a charity's own policies, can also constitute misconduct and mismanagement: Oxfam Inquiry Report: Summary Findings and Conclusions (Commission, 11 June 2019).

${ }^{79} 2011$ Act, s 46(2).

${ }^{80} \mathrm{An}$ inquiry could be prompted by an employee or member of the public.

${ }^{81}$ Making a Commission inquiry subject to a Principal Regulator's request is described as 'a sop' in evidence cited by the Joint Committee, above n 53, para 363.

${ }^{82}$ University of Bath, above $\mathrm{n} 42$.

${ }^{83}$ Both, of course, being registered charities.

${ }^{84} 2011$ Act, s 28.

${ }^{85}$ Ibid, s 52; s 15 .

${ }^{86}$ Ibid, s 85.

${ }^{87}$ Ibid, s 181A.

${ }^{88}$ Ibid, s 75A.

${ }^{89}$ Ibid, s 80.

${ }^{90}$ Ibid, s 80(4).

${ }^{91}$ Higher Education Research Act 2017, s 8. (HEFCE likewise: Further and Higher Education Act 1992, s 79.)

${ }^{92}$ Ibid, ss 18 and 16 respectively.

${ }^{93}$ Ibid, s 15.

${ }^{94}$ University of Bath, above n 42.

${ }^{95} \mathrm{Ibid}$, para 3, Annex paras 2, 3.
} 
appeared to approach the various governance issues in light of the funding condition of good governance, rather than as part of that charity-based role. The OfS did likewise in respect of De Montfort University. ${ }^{96} \mathrm{Had}$ either investigation been carried out as a matter of charity law, the scope would have been broader, and if as a statutory inquiry, more regulatory responses would have been available and possibly exercised to greater effect. ${ }^{97}$

The obligation for the Commission to consult is not to give a power of veto, of course, but there is a concern that it could give rise to delays and potentially undermine the Commission's ultimate authority. ${ }^{98}$ One wonders whether concerns about possible effects on students, or about the reputation of an institution or the sector generally, might influence the OfS in discussions with the Commission regarding a possible statutory warning or disqualification of a governing body member, for example. ${ }^{99}$ Furthermore, since it is the Principal Regulator who monitors information supplied by exempt charities and has the sector-specific knowledge and expertise, the likelihood of the Commission seeking to employ its investigative or regulatory powers on its own initiative seems remote. And, of course, the less information that a charity makes public or is required to provide (or provides) to a Principal Regulator, the less likely such action will be prompted either by the Principal Regulator, or by those involved with the charity, or by members of the public.

The Commission also has facilitative powers, exercisable in response to any charity's request, and, in the case of exempt charities, it must consult with the Principal Regulator. ${ }^{100}$ Thus it may authorise payments or other dealings with charity property if it deems it expedient in the interests of the charity and whether or not the charity otherwise has power in its constitution. ${ }^{101}$ Similarly it can be called upon to authorise ex gratia payments, which a charity is not legally required, or empowered, to make. ${ }^{102}$ Other facilitative powers include giving advice on request, ${ }^{103}$ or authorising legal proceedings. ${ }^{104} \mathrm{~A}$ university proposing to make an ex gratia payment on the termination of an employee's employment, for example, should seek approval from the Commission, who will consult with the OfS. ${ }^{105}$ A similar requirement for the Treasury to authorise exit payments in the public sector was noted to have been frequently overlooked or disregarded and one wonders whether the same might have occurred in the university sector. ${ }^{106}$

\section{(b) The further divide between registered and exempt universities}

There are a number of further instances where the legislative framework differentiates between registered and exempt charities. Some of these are explored below, also highlighting how those discrepancies are brought into sharp focus as a result of the OfS having replaced HEFCE as Principal Regulator.

\footnotetext{
${ }^{96}$ De Montfort, above n 42 .

${ }^{97}$ The Bath report, for example, explained that its primary statutory power, to attach terms and conditions, was restricted to HEFCE-provided monies only (whereas all assets of a charitable university are charitable assets, from wheresoever sourced): University of Bath, above n 42, para 3 and Annex, para 2, respectively.

${ }^{98}$ Or undermine the Principal Regulator; note conflicting evidence on this point: Joint Committee, above n 53, paras 362-364.

${ }^{99}$ The influence of political considerations is not without precedent: M Synge 'The Charity Commission and the Attorney General: one rule without reason' (2016) PL 409 (and note Technical Issues in Charity Law (Law Commission No 375) para 15.67).

${ }^{100} 2011$ Act, s 28; described as rarely used powers: J Hill and E Hackett 'Exempt charities' (1992/93) 1 Charity Law \& Practice Review 209.

${ }^{101} 2011$ Act, s 105.

${ }^{102}$ Ibid, s 106. (See Technical Issues, above n 99, ch 10 for a comparison between s 105 and (the narrower) s 106 and regarding ex gratia payments in statutory charities.)

${ }^{103}$ Ibid, s 110 .

${ }^{104}$ Ibid, s 115; see too ss 111 and 181 .

${ }^{105} \mathrm{Ibid}$, s 106 (eg pension or redundancy payments more generous than demanded by contract or statute: Technical Issues, above n 99, para 10.1).

${ }^{106}$ National Audit Office Confidentiality clauses and special severance payments, HC 130, Session $2013-14$ (TSO, June 2013) paras 14, 15 and 18a. Academy schools, also exempt charities, must obtain the Principal Regulator's consent for noncontractual payments over £50,000: Academies Financial Handbook 2020 (ESFA, June 2020) para 5.10.
} 
(i) Registration and transparency

As registered charities, Welsh universities, the University of Buckingham and the colleges of Oxford, Cambridge and Durham are entered on the public register, together with such information as the Commission thinks fit, ${ }^{107}$ and must notify the Commission of any change in their trusts or particulars. ${ }^{108}$ In practice, the register identifies the governing constitution and sets out the express objects, gives details of trustees and their other trusteeships, describes the institution's activities and provides a history of their compliance with filing requirements. The Commission must keep open to public inspection copies (or particulars) of charities' trusts, ${ }^{109}$ and registered universities are required to declare their registered charitable status on an extensive range of documents, including invoices and fundraising documents. ${ }^{110}$

The charitable status of exempt universities is considerably less visible. Registration is neither required nor possible, ${ }^{111}$ and relevant information on the OfS public register (of English higher education providers) is limited to the institution's name and address and whether it is registered or exempt. ${ }^{112}$ Significantly, the OfS has removed HEFCE's requirement for universities to publish on their websites a 'gateway page', a feature that was 'intended to mirror' the information available on the charities register, including trustees' details and a copy of the institution's constitution. ${ }^{113}$ It has also removed the requirement to include a statement about an institution's charitable objectives in the financial statements, ${ }^{114}$ and the requirements for providing information on an exempt university's corporate governance arrangements are diluted. ${ }^{115}$ It follows that an exempt university's charitable purposes and other particulars are not so readily discoverable by the public and the obligation to declare (exempt) charity status is significantly more limited. ${ }^{116}$

Registration and transparency over trustees and governance will not necessarily promote compliance with any express obligation under charity law, but making such particulars readily discoverable does enhance accountability. Demanding that the charitable objectives be made visible also provides a valuable reminder of a university's charitable status, and of the charitable purposes in respect of which the overriding duty of its trustees to act in the best interests of the charity is formulated and assessed.

\section{(ii) Accounts}

Universities registered by the Commission must file full audited accounts and an auditor's report, ${ }^{117}$ together with a Trustees' Annual Report that gives details of the year's activities. ${ }^{118}$ An Annual Return is also required. ${ }^{119}$ In addition to certain disclosures (considered below), this contains detailed questions, including questions about payments to trustees, whether trustees are directors of an institution's subsidiaries and whether the institution has reviewed its financial controls. ${ }^{120}$ Other questions, compulsory from 2019, demand more detailed information about funds received from overseas,

\footnotetext{
${ }^{107} 2011$ Act, s 29(2).

${ }^{108}$ Ibid, s 35(3).

${ }^{109}$ Ibid, s 38(4).

${ }^{110}$ Ibid, s 39; see too s 194 .

${ }^{111}$ Ibid, s 30 .

${ }^{112}$ Also noting the authority for using the title 'university' (eg charter or statute).

${ }^{113}$ Memorandum of assurance and accountability between HEFCE and institutions (HEFCE, July 2012) Annex E, para 5.

${ }^{114}$ Only a statement that the university is an exempt charity is required: Regulatory Advice 9: Accounts Direction 2019.41 (OfS, October 2019) (RA9) para 47; cf Memorandum, ibid, Annex E, para 7a.

${ }^{115} \mathrm{cf}$ Memorandum, above n 113, paras 29 and 34; RA9, ibid, para 21.

${ }^{116} 2011$ Act, s 39 does not apply; by contrast, s 194 and s 122 are broadly similar for registered and exempt charities (but somewhat confusingly summarised in Regulatory Advice 5: Exempt Charities 2018.23 (OfS, May 2018) (RA5), para 25a, Annex A paras 2, 5).

${ }^{117} 2011$ Act, ss $130-164$.

${ }^{118}$ Ibid, s 162 (publicly available: ss $170-172$ ).

${ }^{119}$ Ibid, s 169.

${ }^{120}$ The Charities (Annual Return) Regulations 2017.
} 
monitoring of overseas expenditure and transactions outside the regulated banking system. ${ }^{121}$ These have been prompted by concern over money laundering and other financial impropriety, amid falling trust and confidence in the charity sector. Although not made public, the answers allow the Commission to take regulatory action where appropriate. The OfS does not subject exempt universities to scrutiny in this way, the rationale presumably being that the statutory obligation to submit an Annual Return is imposed on registered charities only. ${ }^{122}$

Statute expressly excludes exempt charities from those provisions applicable to registered charities that deal with accounts ${ }^{123}$ and auditors ${ }^{124}$ and there is no requirement to file a Trustees Annual Report ${ }^{125}$ or Annual Return. ${ }^{126}$ They must, however, keep proper books of account, ${ }^{127}$ and comply with the Principal Regulator's requirements. ${ }^{128}$ In theory, of course, these requirements could be more onerous than those applicable to registered charities, and even low-risk institutions must still provide full audited financial statements and financial forecasts, ${ }^{129}$ but the OfS has removed the need for exempt universities to prepare accounts in accordance with the 'Statement of Recommended Practice: accounting for further and higher education' (SORP FHE) ${ }^{130}$ As a result, the OfS no longer requires exempt universities to prepare a Strategic Report, the contents of which are not entirely dissimilar to a Trustees' Annual Report, and there are notable discrepancies relating to the disclosures required. ${ }^{131}$

\section{(iii) Fundraising disclosures}

Charity fundraising is self-regulated to a great extent. Overseen by the Fundraising Regulator, a voluntary scheme encompasses both registered and exempt charities, and fundraising undertaken by professional fundraisers, subsidiaries, or in-house. Charities may choose to register and agree to comply with the Fundraising Code, which provides a robust and comprehensive guide to legal obligations and good practice. ${ }^{132}$ Those with fundraising costs over $£ 100,000$ pay an annual levy which is calculated on a sliding scale, although all universities pay a fixed fee. ${ }^{133}$ Statute requires that where a professional fundraiser is engaged, by either a registered or exempt charity, a written agreement must be completed that satisfies prescribed requirements. ${ }^{134}$ It is only registered charities, however, that are required by statute to explain their approach to fundraising in their Annual Report, including actions taken to protect vulnerable persons, whether any voluntary scheme was adopted (together with details of any noncompliance) and the number of complaints received. ${ }^{135}$

\footnotetext{
${ }^{121}$ Ibid, Part B.

${ }^{122}$ Above n 119.

${ }^{123} 2011$ Act, ss 136, 143.

${ }^{124}$ Ibid, s 166.

${ }^{125}$ Ibid, s 167 .

${ }^{126}$ Ibid, s 169 (registered charities only).

${ }^{127}$ Ibid, s 136.

${ }^{128}$ A registered company university (rare) must also comply with companies legislation.

${ }^{129}$ Securing student success: regulatory framework for higher education in England 2018.01 (OfS, February 2018) (Regulatory Framework) para 416; the financial statements are explicitly noted 'not [to] relate to a provider's status as an exempt charity or otherwise': RA5, above n 116, Annex A5. (Higher risk institutions face greater scrutiny: Regulatory Framework, para $421 \mathrm{ff}$.)

${ }^{130}$ Published by Universities UK (July 2014); see RA9, above n 114, para 30, fn 8 (though still requiring compliance with (the less demanding) Financial Reporting Standard 102). Adoption of the SORP FHE was required by HEFCE (Accounts Direction, Circular Letter 19/2016 (29 July 2016)) and permitted by the Commission as a recognised alternative to the Charities SORP (Charity reporting and accounting: the essentials CC15d (Commission, November 2016) 2.7).

${ }^{131}$ Nor are details of payments to trustees or expenses now required (SORP FHE, 3.15).

${ }^{132}$ Code of fundraising practice (Fundraising Regulator, June 2019) available at https://www.fundraisingregulator.org.uk/ code.

${ }^{133}$ Of $£ 1,000$ (equivalent to a fundraising spend of $£ 500,000-£ 749,000$, somewhat below the mean expenditure noted in Giving to excellence: philanthropic support for higher education (Ross-Case 2019) available at https://www.case.org/system/ files/media/file/ROSS-CASE\%20UK\%20Report\%20Final\%204\%2029.pdf).

${ }^{134}$ Charities Act 1992, s 59.

${ }^{135}$ And whether a professional fundraiser has been engaged: 2011 Act, s 162A.
} 
The Commission 'expects all charities that fundraise to fully comply with the Fundraising Code'. ${ }^{136}$ As Principal Regulator, HEFCE strongly encouraged higher education institutions to register with the Fundraising Regulator, to pay the voluntary levy and voluntarily to disclose in their financial statements the same information regarding their fundraising practices that registered charities are statutorily obliged to disclose. ${ }^{137}$ By contrast, the OfS seems only to encourage institutions to subscribe to a mailing list, in order to receive charity law updates and guidance issued by the Commission and Fundraising Regulator. ${ }^{138}$ It is possible, of course, that exempt universities will continue to make information transparent and renew their subscriptions to the Fundraising Regulator, but the omission of fundraising from the OfS's Accounts Direction and summary of applicable charity law may make that prospect less likely. ${ }^{139}$

There is no legal obligation for exempt universities to report, nor to support the Fundraising Regulator, but reporting does offer greater transparency and, especially where the Fundraising Code is adopted, may demonstrate compliance with the fundamental duties of care and acting in the best interests of the charity that apply to all charities. ${ }^{140}$ Urging support of the scheme for self-regulation also signals an upholding of values that can serve to promote trust and confidence and, as HEFCE outlined, enhance the reputation of the higher education sector. ${ }^{141}$

\section{(iv) Remuneration disclosures}

The issue of executive remuneration in the university sector has received intense scrutiny in recent years. Space does not allow a detailed comparison between information published by charities generally, registered universities and exempt universities. Suffice it to say that the more extensive obligations imposed by HEFCE, which broadly reflected those placed on registered charities, have been considerably reduced by the OfS. ${ }^{142}$ Like HEFCE, however, the OfS requires detailed public disclosure regarding remuneration of the head of provider. ${ }^{143}$ Viewing such transparency as 'an important regulatory tool', this information is required in the expectation that it will enable staff and students to 'push for changes' where pay is 'out of step with stakeholders' expectations'. ${ }^{144}$ This might appease political frustration with the 'endless upwards ratchet of Vice-Chancellors' pay', ${ }^{145}$ but whilst increased transparency may make challenge more informed, it does not necessarily make it more likely (except, perhaps, through media attention). ${ }^{146}$ Promoting compliance with charity law calls for more.

As noted above, members of governing bodies of exempt universities, as much as those of registered universities and charities generally, are subject to the legal requirement that benefits to trustees and employees should be in the best interests of the charity and in accordance with established rules

\footnotetext{
${ }^{136}$ Charity fundraising: a guide to trustee duties CC20 (Commission, November 2016) section 3 (emphasis added).

${ }^{137}$ Update on fundraising regulation and practice CL29/2016 (HEFCE, 2016) paras 4 and 7.

${ }^{138} R A 5$, above n 116 , para 22.

${ }^{139}$ Ibid, Annex A; also omitted at Regulatory Advice 1: The OfS approach to regulation 2018.02 (February 2018) para 34 (RA1) and not prominent (and in need of updating) in guidance issued by Universities UK: Strategic Fundraising (Universities UK, August 2014) eg pp 29, 31.

${ }^{140}$ And with the statutory obligation that applies to registered and exempt charities alike (above n 134). (The Code signals useful reminders about the need to act in the best interests of the charity in refusing or accepting donations, for example.)

${ }^{141}$ CL29/2016, above n 137, para 4.

${ }^{142}$ Including removing the requirement for disclosure of payments to trustees, together with the legal authority and reason for such payments. Compare Memorandum, above n 113, Annex E para 7 and CL29/2016, above n 137, on the one hand, and $R A 9$, above $\mathrm{n} 114$, on the other; and note text to $\mathrm{n} 130$ above.

${ }^{143} R A 9$, above $\mathrm{n} 114$, para 12 , the level of information being slightly more detailed than HEFCE required (CL19/2016, above $\mathrm{n}$ 137, para 13). (The Commission requests (but does not publish) information regarding the highest salary: Regulations, above n 120.)

${ }^{144}$ Senior Staff Remuneration, Analysis of the 2017-18 disclosures 2019.03 (OfS, 12 February 2019) para 25.

${ }^{145}$ Jo Johnson, 2017: available at https://www.timeshighereducation.com/news/universities-minister-says-uk-vice-chancellors-are-paid-too-much; and see guidance, above n 19.

${ }^{146}$ The House of Commons Education Committee described the 'system of self-regulation' as 'totally unacceptable' and the 'unjustifiably high pay for senior management' as 'the norm rather than the exception': Value for Money in Higher Education, $7^{\text {th }}$ Report, 5 Nov 2018 (HC 343) paras 28 and 27 respectively.
} 
relating to private benefit. Disclosures are not, however, framed in these terms and guidance for universities stands in stark contrast to that published for charities generally. The latter is issued by the National Council for Voluntary Associations (NCVO), and endorsed by the Commission. ${ }^{147}$ It refers to the 'vast majority of paid charity leaders' who receive $25-45 \%$ 'less pay than they could command elsewhere', questions the use of incentive pay schemes and cautions against the use of both market comparators (which are noted to drive up pay in the business sector) and ratios (that can be easily manipulated). ${ }^{148}$ The guidance published by the Committee of University Chairs (CUC), on the other hand, emphasises the 'intensively competitive global environment' in a sector with $2.2 \mathrm{~m}$ students and generating over $£ 95$ bn gross output to the economy. ${ }^{149}$ It suggests international higher education providers as comparators and also notes the 'significantly higher' pay levels in the US and Australia (without consideration of other contextual differences). The charitable context is not evident. The OfS requires compliance with the CUC guidance. ${ }^{150}$ The Commission's intentions are less clear, but one assumes that it would recognise the NCVO guidance as a more helpful reflection of charity law. ${ }^{151}$

The OfS also requires exempt universities to have regard to CUC guidance on severance payments. ${ }^{152}$ This is generally less prescriptive than HEFCE's guidance, ${ }^{153}$ for example in rendering optional both the obtaining of legal advice and consideration of the government's consultation on exit payments in the public sector. It also removes the direction to members of the governing body to consider their responsibilities 'as charity trustees', save that they are reminded that a charitable university's assets can only be used to further charitable purposes. ${ }^{154}$

Many Vice-Chancellors are reported to be stepping down from remuneration committees, ${ }^{155}$ possibly in response to HEFCE's report into governance at the University of Bath, ${ }^{156}$ and there is evidence that baseline pay levels may also be reducing. ${ }^{157}$ Public pressure might achieve welcome results, but it is a poor substitute for a statutory regulator, and is unlikely to achieve consistent results. ${ }^{158}$ Greater awareness of charity law principles, and closer observance of them, might have avoided this rather disappointing display of governance standards in the sector.

There is scope for promoting compliance with charity law more effectively, by both registered and exempt universities. They could, for example, be required to publish an 'explanation and justification' of how levels of pay, including incentive schemes and termination packages, are in the best interests of the charity, echoing the NCVO's guidance for large charities. ${ }^{159}$ They could also be required to state

\footnotetext{
${ }^{147}$ NCVO Report of the Inquiry into Charity Senior Executive Pay and Guidance for Trustees on Setting Remuneration (April 2014) (NCVO Guidance) p 6.

${ }^{148}$ Ibid (quotation at $\mathrm{p} 4$ ). Universities are excluded for statistical purposes only ( $\left.\mathrm{p} 10\right)$.

${ }^{149}$ The Higher Education Senior Staff Remuneration Code (CUC, June 2018) para 1; see too The Context for the Higher Education Senior Staff Remuneration Code, both available at https://www.universitychairs.ac.uk/publications/.

${ }^{150}$ Although the CUC Code itself is expressed to be optional.

${ }^{151}$ HEFCE recommended universities' remuneration committees to consider remuneration 'in the context of charity law', to follow the CUC Code and to have regard to guidance published for charities generally: Guidance on severance pay and remuneration of senior staff (CL17/2017, 15 June 2017).

${ }^{152}$ Guidance on decisions taken about severance payments in HEIs (CUC, June 2018) available at https://www.universitychairs.ac.uk/publications/; cf CL17/2017 (ibid).

${ }^{153} \mathrm{CL} 17 / 2017$, above n 151.

${ }^{154}$ CUC Guidance, above n 152 (but note confusion regarding use of charity assets in paras 3 and 8).

${ }^{155}$ The CUC Guidance, above n 152, states that heads of institutions must not be members of remuneration committees and that no member can be involved in deciding his or her own remuneration, although they may be invited to attend. Previously, the CUC had indicated that the head of the institution 'may or may not be a member': Illustrative Practice Note 1: Remuneration Committees (CUC, March 2015) para 18.

${ }^{156}$ University of Bath, above $\mathrm{n} 42$.

${ }^{157}$ Senior Staff Remuneration, above n 144.

${ }^{158}$ See eg 'Vice-Chancellors still attending pay meetings, despite outcry' (Guardian, 20 June 2019) available at https://www. theguardian.com/education/2019/jun/20/vice-chancellors-still-attend-pay-meetings-despite-outcry.

${ }^{159}$ NCVO Guidance, above n 147, p 4: to be included on an institution's webpage, putting 'proper pressure on trustees to justify publicly how their decisions on high-level pay square with their legal obligation to give constant priority to the best interests of the charity and its beneficiaries'.
} 
openly that no conflicts of interest have been present or, with supporting details, how these have been properly managed. As with fundraising matters, a duty to report raises awareness of the legal requirements, focuses the attention of the governing body, demonstrates compliance and promotes trust and confidence. Essentially, it makes compliance less likely to be overlooked.

\section{(v) Public benefit}

The public benefit requirement is equally applicable to all charities, ${ }^{160}$ as is the statutory obligation to have regard to the Commission's guidance on public benefit, ${ }^{161}$ but it is only registered charities (including universities that are registered) that are required by statutory regulations to report on significant activities and to relate these to their charitable purposes and strategic objectives. ${ }^{162}$ Whereas HEFCE required exempt institutions to report along the same lines, ${ }^{163}$ the OfS does not. It simply reminds exempt universities of the need to have regard to the Commission's guidance, ${ }^{164}$ which they are 'advised' to read. ${ }^{165}$ Whilst statute expressly imposes formal reporting obligations on registered charities only, such reporting does enable any charity to demonstrate performance of the obligations that are not confined to registered charities, and to improve public trust and confidence. The OfS's willingness to forgo the transparency demanded by HEFCE is, for this reason, regrettable. ${ }^{166}$

On one level, it should not matter: the public benefit requirement is a statutory requirement that relates to charitable status and requires that an institution's purposes are for the public benefit. This should not be in doubt in respect of a non-profit making university. ${ }^{167}$ The Commission's guidance, however, states - in the case of a charity that charges fees that are not easily affordable by people of modest means - that this requirement obliges the charity 'to make provision for the poor to benefit'. ${ }^{168}$ It has been argued elsewhere that this position has been arrived at through a flawed process of legal interpretation and law-making, not least through having confused charitable status and trustees' duties. ${ }^{169}$ Nonetheless, if such an obligation is (or is treated as being) a legal requirement with which charities must comply, then there seems no logical or rational justification for excusing some charities from it, and that includes both registered and exempt universities. Notwithstanding the substantial increase in university fees since the public benefit requirement was enacted, and the apparent overlap between this representation of the law and the widening participation agenda in the university sector, the Commission seems disinclined to apply this law to universities. ${ }^{170}$ The view of the Secretary of State for Education, that 'too much focus on bursaries can have the effect of cherry-picking a small number of students at the expense of others who also have the potential to benefit', ${ }^{171}$ is potentially at odds with the Commission's legal interpretation of public benefit.

\footnotetext{
${ }^{160} 2011$ Act, s 4(1).

${ }^{161}$ Ibid, s 17(5).

${ }^{162}$ Charities (Accounts and Reports) Regulations 2008, SI 2008/629.

${ }^{163}$ Memorandum, above n 113, Annex E paras 7c and 7d; see too SORP FHE (text to n 130) 3.15.

${ }^{164} R A 5$, above $\mathrm{n} 116$, para 8.

${ }^{165}$ Ibid, para 5.

${ }^{166}$ Academy schools must report on public benefit as if registered: Exempt charities and the role of the Secretary of State as Principal Regulator (Department of Education, February 2014).

${ }^{167}$ Assurances were given that universities were not in the reformers' sights in the same way as 'elite' independent schools: eg Hansard HL Deb, vol 669, col 74GC, 9 February 2005.

${ }^{168}$ Public benefit: running a charity PB2 (Commission, September 2013) Annex C (noting that student loans can be taken into account in deciding how much provision to make).

${ }^{169} \mathrm{M}$ Synge The 'New' Public Benefit Requirement: Making Sense of Charity Law? (Oxford: Hart Publishing, 2015); H Picarda 'Dog's breakfast or a dream come true' in M Harding et al (eds) Not-For-Profit Law: Theoretical and Comparative Perspectives (Cambridge: Cambridge University Press, 2014).

${ }^{170}$ It is, for example, not mentioned in Registration of Welsh Universities (Commission, May 2013).

${ }^{171}$ Secretary of State for Education guidance to the OfS: Access and Participation (Department of Education, February 2018) para 53.
} 


\section{(vi) Serious incident reporting}

There is no statutory duty on a charity (as opposed to its auditors) to report matters of concern, ${ }^{172}$ although the Commission does require (or expect) registered charities to report 'serious incidents' and regulations require annual confirmation that there are none that have not been reported to it. ${ }^{173}$ These incidents are described as those resulting in, or risking, significant loss of a charity's money or assets, damage to its property or harm to its work, reputation or those coming into contact with it. ${ }^{174}$ Extensive examples include large donations from unknown or unverifiable sources, suspicions or allegations of abuse and links to terrorism or extremism. Receiving reports of serious incidents is a vital tool in the Commission's regulatory armoury.

HEFCE followed the Commission's lead, requiring institutions to report serious incidents to it and signposting that such reports could lead it to request the Commission to instigate a statutory inquiry. ${ }^{175}$ Specifically, it required full details of unverifiable donations over $£ 25,000$, abuse of students, disqualification of trustees and alleged or real links to terrorism. ${ }^{176}$

By contrast, the OfS has removed this obligation, requiring only that institutions should notify it of 'reportable events', principally those events which might materially affect the 'legal form or business model and/or [the provider's] willingness or ability to comply with its conditions of registration'. ${ }^{177}$ This represents a significantly narrower area of concern and is more akin to the 'other significant events' of which HEFCE also expected to be notified. ${ }^{178}$ Regulatory investigations or sanctions by the Commission (or other regulators) are included, ${ }^{179}$ so that a trustee disqualification would constitute a reportable event, but the fact that a trustee is automatically disqualified (without investigation or sanction) would appear to fall outside the OfS's area of concern. Likewise, discovery of a significant data breach or an alleged link between a member of staff and an extremist organisation, for example, would not be reportable to the OfS, but should be reported (by a registered university) to the Commission and should previously have been reported (by an exempt university) to HEFCE.

One suspects that the OfS has removed this obligation on the basis that it, too, is not legally required' as a matter of charity law. ${ }^{180}$ This is arguable, ${ }^{181}$ but since a failure to report adequately can undoubtedly constitute evidence of misconduct or mismanagement, ${ }^{182}$ it would seem that reporting serious incidents does provide a useful mechanism for prompting awareness of issues that are relevant to the all-important duties of care and skill and acting in the best interests of the charity. ${ }^{183}$ It can also promote trust and confidence by demonstrating responsibility in dealing with such issues and put the OfS on notice of any need to request the Commission to institute an inquiry. For a body charged

\footnotetext{
${ }^{172}$ The statutory duty on a charity's auditors (2011 Act, s 156(2)), modified (somewhat unclearly) for exempt charities (s 160), is inadequately and inaccurately summarised by the OFS: RA5, above n 116, Annex 1, para 2.

${ }^{173}$ Annual Return (answer not published): Regulations, above n 120, reg 31.

${ }^{174}$ How to report a serious incident in your charity (Commission, June 2014, updated June 2019), available at https://www. gov.uk/guidance/how-to-report-a-serious-incident-in-your-charity\#what-to-report.

${ }^{175}$ Memorandum, above n 113, Annex E, paras 9-16.

${ }^{176}$ Ibid, para 12.

${ }^{177}$ Regulatory Framework, above n 129, para 494. Problematically, the events are those that the OfS (not the provider) considers could materially affect legal form etc.

${ }^{178}$ Memorandum, above n 113, para 57 (in addition to 'material adverse events', including threats to an institution's financial position or major accounting breakdown (para 56)).

${ }^{179}$ Regulatory Framework, above n 129, para 494g.

${ }^{180} R A 5$, above n 116, see paras 1, 24; similarly, RA9, above n 114, para 25.

${ }^{181}$ By reference to the 2011 Act, s 20(1).

${ }^{182}$ Statement of the results of an Inquiry: Oxfam (Commission, June 2019) (a registered charity but the same would reasonably apply to any charity).

${ }^{183}$ Arguably such events could be considered reportable, as affecting an institution's ability to comply with the regulator's conditions of funding, but their omission from a long list of examples (and the divergence from HEFCE's advice) might suggest otherwise.
} 
with doing all it reasonably can to promote compliance with charity law, this would seem to be an effective and efficient tool at its disposal. ${ }^{184}$

\section{The statutory duty of the Principal Regulator to do 'all it reasonably can'}

On the face of it, then, the legislative framework appears to subject exempt charities to less explicit and less extensive regulation than registered charities, and to place them one step removed from the fuller regulatory powers of the Commission. In the university sector, this two-tier regime has been accentuated by a new Principal Regulator that appears to confine 'charity law' to statutory obligations only and carefully disregards any that are imposed specifically on registered charities. Such an approach, however, ignores (and fails to promote) the greater part of that body of law.

The OfS acknowledges this 'marked shift for the sector', ${ }^{185}$ and justifies it on the basis of its statutory duty to observe 'best regulatory practice'. ${ }^{186}$ Whilst being 'economic and efficient' can mould the exercise of the duty, however, it cannot redefine it and reducing the information that is collected and published inevitably reduces both the likelihood of 'targeting action where needed' (including requesting an inquiry) and the prospect of an exempt university, or its governing body, being otherwise challenged or held to account. Sharing charity law updates and guidance from the Commission and Fundraising Regulator through a mailing list to which institutions are encouraged (but not obliged) to subscribe, and promising to work with other agencies to develop relevant guidance, ${ }^{187}$ is inadequate. Agreeing to notify the Commission if it has 'concerns about a breach of charity law', or becomes aware of 'any other matter in which the Charity Commission has a regulatory interest', similarly inspires little confidence when the significance that it attaches to charity law appears to be so limited and its efforts to educate and encourage (let alone monitor) universities' compliance so diluted. ${ }^{188}$ As Principal Regulator, the OfS barely merits the title of 'information-gatherer'.

For the OfS, a reduced regulatory burden goes 'hand in hand' with facilitating 'an excellent education to all students', ${ }^{189}$ and achieving and maintaining 'open and trusting relationships with providers' is said to deliver 'the mechanism best able to achieve effective regulation'. ${ }^{190}$ Neither proposition seems compelling. The test of whether the OfS is performing its statutory role is an objective one and not whether the OfS matches a predecessor's efforts, but there seems little reason to expect or excuse any lesser effort on the OfS's part. Exempt universities might, of course, continue to offer the same level of transparency and accountability that HEFCE demanded, and which still applies to registered universities, but the proclaimed priorities of the OfS (together with the sector's historical resistance to regulation) would suggest otherwise. Any notion that other forms of regulation of higher education institutions somehow encompass charity law regulation is as mistaken now as it was in 2006.

\section{A case for reform}

In the statutory five-year review of the 2006 Act, concerns that some Principal Regulators were not taking their role seriously were noted, but others were reported to be doing 'an excellent job'. ${ }^{191}$ No doubt reassured by HEFCE, the only Principal Regulator to submit evidence to the Review,

\footnotetext{
${ }^{184}$ Higher Education Research Act 2017, s 8(1)(b) not being limited to one-off requests. (The OfS has also removed the need for exempt universities to seek its consent before increasing financial commitments as HEFCE had required: compare OfS Terms and Conditions of funding for higher education institutions, 2018.15 (March 2018) Annex D and Regulatory Framework, above n 129, para 175 with Memorandum, above n 113, Annex C.)

${ }^{185}$ Regulatory Framework, above n 129, paras $15,16$.

${ }^{186} R A 9$, above $\mathrm{n} 114$, para 25; RA5, above n 116, para 24; Higher Education Research Act 2017, s 2(1)(g).

${ }^{187}$ None has yet been produced.

${ }^{188} R A 5$, above $\mathrm{n} 116$, para 22; see also Memorandum of Understanding (Commission and OfS, February 2019).

${ }^{189}$ Regulatory Framework, above n 129, foreword.

${ }^{190}$ Ibid, para 25.

${ }^{191}$ Trusted and Independent, above n 51, para 6.7.
} 
Lord Hodgson appeared satisfied that the system of exempt charities and Principal Regulators was 'generally working well' and that the challenges were 'not sufficiently serious to merit the removal of the system'. ${ }^{192}$ One wonders if he might have concluded differently post-HEFCE.

The two-tier regime that applies to universities may represent an anomaly in the regulatory framework, but it does serve to highlight the discrepancies between registered and exempt charities more generally. It also provides a compelling case for questioning again why all charities should not be placed under the full regulatory jurisdiction of the Commission, whether or not they are also registered, at the same time bringing England and Wales in line with other comparable jurisdictions. ${ }^{193}$ Viscount Eccles was surely right, that an 'extremely strong argument has to be made in order to appoint any charitable [sic] regulator other than the Charity Commission'. ${ }^{194}$

In the university sector in particular, the two-tier regime appears irrational and unsupportable and the policy behind the 2006 reforms, both to increase compliance and to develop a level playing field, has been further undermined by the approach taken by the OfS. Whether or not conflicted as funder, ${ }^{195}$ the fundamental conflict that arises from the mandate, in effect, to substitute the interests of students for the best interests of the charity prevents the OfS from impartially and effectively promoting (or regulating) compliance with a core tenet of charity law. ${ }^{196}$ And its declaration that it 'will discharge its obligations as Principal Regulator as part of its routine monitoring activities' has been shown to be lacking. ${ }^{197}$

Effective regulation of charities is critical, but inevitably there are limitations to what a statutory regulator can achieve and this brief review of charity law regulation in the university sector has also pointed to some of its shortcomings. As the Commission reminds the charity sector, charity law is about more than complying with legal minimum standards set out in statute, and full compliance - as with public trust and confidence - depends on the knowledge, integrity and values of the charity trustees, both lay and executive members, and their willingness to be transparent. ${ }^{198}$ The more fundamental aspects of charity law do not lend themselves to tick-box regulation and transparent disclosures are useful only to the extent that they facilitate effective challenge and accountability. Notwithstanding its limitations, however, regulatory oversight can, and should, be improved.

A useful starting point would be for the Commission to publish guidance that highlights aspects of charity law which are particularly relevant to universities (both registered and exempt). The Commission should not shy away from reminding universities of, and explaining, the obligation to act only in the best interests of the charity and what this might mean in practice, ${ }^{199}$ nor from reminding governing bodies of the charitable context in which they operate, including in determining executive pay. ${ }^{200}$ In doing so, it should seek to promote compliance with the full range of charity law, including the need to address and observe both statutory and common law duties. The Commission might also adapt its regulatory practices so that universities are required to demonstrate

\footnotetext{
${ }^{192}$ Ibid.

${ }^{193}$ Other common law jurisdictions have recently passed legislative measures for registration and regulation, but none includes classes of 'exempt charities' (eg New Zealand (2005), Scotland (2005), Northern Ireland (2008), Ireland (2009) and Australia (2013)).

${ }^{194}$ Hansard, above n 11, col 1634 (Viscount Eccles).

${ }^{195}$ Above n 65.

${ }^{196}$ Above, text to nn 15-19. The Secretary of State for Education, although Principal Regulator in some sectors, should not assume the role for the same reason (and because independence from the state (a hallmark of charity) may be especially challenging in the higher education sector: Independence of charities from the State RR7 (Commission, October 2009)).

${ }^{197}$ Regulatory framework, above n 129, para 160.

${ }^{198}$ See eg Oxfam, above n 182.

${ }^{199}$ It is suggested that the Commission's guidance for Welsh universities, above n 170, could be considerably improved.

${ }^{200}$ Making public a justification that explicitly reflects charity law principles, for example, whilst not guaranteeing reductions in pay, might prevent criticism that levels of pay are unnecessarily high or a product of too much involvement by executives or corporate-driven governors, without due regard to charitable status, purpose and principles.
} 
their awareness of, and compliance with, the full range of charity law obligations. In respect of universities that remain exempt, it should expect the same of the OfS. ${ }^{201}$ When Lord Hodgson suggested that the Commission should do more to work with Principal Regulators that are not discharging their duty 'as fully as others', ${ }^{202}$ it is clear that HEFCE was not considered to be a candidate. The OfS, however, would seem to fit the bill.

Still more is needed. A first option, which assumes the continued existence of exempt charities (including some universities) and requires amending legislation, would be to replace the name 'Principal Regulator' and to discontinue the term 'exempt': 'Co-Regulator' and 'co-regulated charities' seem more accurate. ${ }^{203}$ The Commission should be empowered to conduct a statutory inquiry on its own initiative and the Co-Regulator, as currently empowered, should be under a duty to request an inquiry when circumstances demand it. Full co-operation between the Commission and Principal Regulator is imperative. ${ }^{204}$ It is submitted that describing the duty as one that requires a Co-Regulator to 'do all it reasonably can...' should be sufficient, ${ }^{205}$ although a more explicit articulation of the statutory duty would undoubtedly offer greater clarity and render its performance more susceptible to effective review. Amending legislation might oblige the Co-Regulator, for example, to gather and publish at least the same information as the Commission (in respect of registered charities), or statutory reporting obligations might be extended to co-regulated charities. ${ }^{206}$ Such moves would undoubtedly lead to claims of excessive burden being placed on charitable institutions, but unless such oversight stems from other regulatory mechanisms, the 'level playing field' demands them. ${ }^{207}$

A second, and preferred option, would be to remove exempt charitable status from universities and subject them to the Commission's significantly greater expertise in charity law and practice. Such reform could be achieved relatively easily, by an order of the Secretary of State, ${ }^{208}$ and would replace anomaly with coherence. ${ }^{209}$ It has been suggested that the OfS is not best placed to oversee exempt universities for charity law purposes, even less the entire sector. ${ }^{210}$ It does not seem untoward to ask currently exempt universities to register with the Commission as others have done. Much was made of the downsides of multiple regulatory regimes, but any degree of overlap may be smaller than feared. The OfS would continue to oversee matters of education, student choice and financial viability, while the Commission would focus on matters of charity law, as it must for registered universities. ${ }^{211}$ Current arrangements between the two regulators could be modified and strengthened in a revised memorandum of understanding. The Commission's finite resources are acknowledged, ${ }^{212}$ but the cost of registering currently exempt universities (at least where charitable status is not in doubt) would not appear to be unduly onerous. It is entirely possible, however, that the Commission should be more generously resourced in order to exercise the level of regulatory oversight that was intended by the statutory reforms and that may well prove to be of significant benefit both in the university sector and beyond.

\footnotetext{
${ }^{201}$ The Memorandum of Understanding, above $\mathrm{n} 188$, appears to endorse the discrepancies noted in this article.

${ }^{202}$ Trusted and Independent, above n 51, para 6.7

${ }^{203}$ Lord Hodgson suggested 'Co-Regulator' as 'more fitting': Trusted and Independent, above n 51, para 6.10.

${ }^{204} \mathrm{Ibid}$, para 6.7, arguably going further than the Memorandum of Understanding, above $\mathrm{n} 188$.

${ }^{205}$ The degree of flexibility it offers seems practical and not unduly inadequate.

${ }^{206}$ Appearing logical, since the underlying (charity) obligations are the same.

${ }^{207}$ It is envisaged that this reform would be of general application, but its adoption would be subject to being satisfied that it would be neither disadvantageous nor inappropriate in respect of any other exempt charity or class of exempt charities.

${ }^{208} 2011$ Act, s 23.

${ }^{209}$ It could also be replicated in respect of other exempt charities, or classes of exempt charities, if appropriate, with amending legislation only needed if extended to all.

${ }^{210}$ Hansard, above n 54, col 405GC (unlikely, given the OfS's territorial remit and current funding arrangements).

${ }^{211}$ Universities could also be substantial contributors to the proposed scheme for a levy on charities to fund the sector's regulator.

${ }^{212}$ See eg Annual Report, above n 37, p 30; Statement, above n 41 (where the Commission described its strategic objectives as greater than its capacity to deliver).
} 


\section{Conclusion}

There is no obvious reason why the University of Bristol should be held to account as a charity less rigorously than Cardiff University, or the University of Oxford less rigorously than Balliol College, but this has been seen to be the case. In part, this is due to the letter of the statutory framework, but the OfS's chosen approach, in deliberate contrast to its predecessor's, has also thwarted the spirit of the 2006 reforms: the level playing field has not been achieved and the risk of the word 'exempt' being misunderstood has not diminished. The incidental aim of minimising any increase in the regulatory burden was not intended to relieve charities of any burden whatsoever and should not be taken too far.

Neither promoting nor demonstrating compliance with charity law should be seen as an inconvenience, still less an irrelevance. On the contrary, each presents an opportunity. The 2006 Act offered a brave, if inadequate, reminder that universities are charities and subject to charity law. What is needed now is a greater appreciation of how charity law is relevant to universities and greater priority afforded to its observance. The growing criticism in the literature of top-down management and some university operations undoubtedly invites scrutiny of governance structures and practices. To approach that task through a charity law lens is logical and, it is suggested, likely to prove valuable in improving transparency and accountability within institutions. External regulation has a vital role to play in promoting observance of both charity law and charity values.

The Commission has a separate statutory objective 'to increase public trust and confidence in charities' and it has been suggested that it turns its attention to the university sector and the OfS's part in regulating those institutions that are not in the Commission's immediate sights. ${ }^{213}$ Seizing this opportunity could go a long way towards discharging that duty, potentially also improving trust and confidence levels in itself as regulator and in the higher education sector. A charity-conscious university that chooses to demonstrate how it puts its charitable purpose and status clearly at the centre of its decision-making could do likewise. There is considerable benefit to be gained. The 2006 Act moved things one step forward. Pressure needs to be brought to bear, if the OfS is not to be permitted to succeed in taking us two steps back.

\footnotetext{
${ }^{213} 2011$ Act, s 14 .
}

Cite this article: Synge M (2021). Regulation of universities as charities: one step forward, two steps back. Legal Studies 41, 214-233. https://doi.org/10.1017/lst.2020.39 